\title{
The local impacts of climate change in the Ferlo, Western Sahel
}

\author{
Lars Hein • Marc J. Metzger · Rik Leemans
}

Received: 7 December 2006 / Accepted: 21 August 2008 / Published online: 10 October 2008

(C) The Author(s) 2008. This article is published with open access at Springerlink.com

\begin{abstract}
Recent increases in the accuracy of climate models have enhanced the possibilities for analyzing the impacts of climate change on society. This paper explores how the local, economic impacts of climate change can be modeled for a specific ecoregion, the Western Sahel. The people in the Sahel are highly dependent on their natural resource base, and these resources are highly vulnerable to climate change, in particular to changes in rainfall. Climate models project substantial changes in rainfall in the Sahel in the coming 50 years, with most models predicting a reduction in rainfall. To connect climate change to changes in ecosystem productivity and local income, we construct an ecological-economic model that incorporates rangeland dynamics, grazing and livestock prices. The model shows that decreased rainfall in the Sahel will considerably reduce local incomes, in particular if combined with increases in rainfall variability. Adaptation to these climate change projections is possible if reductions in rainfall are followed by destocking to reach efficient grazing levels. However, while such a strategy is optimal from the perspective of society, the stocking rate is determined by individual pastoralists that face few incentives to destock.
\end{abstract}

L. Hein $(\bowtie) \cdot$ M. J. Metzger · R. Leemans

Environmental Systems Analysis Group, Wageningen University,

P.O. Box 47, 6700 AA Wageningen, The Netherlands

e-mail: lars.hein@wur.nl

M. J. Metzger

Alterra Wageningen University and Research Centre,

P.O. Box 47, 6700 AA Wageningen, The Netherlands

M. J. Metzger

Centre for the Study of Environmental Change and Sustainability (CECS),

School of Geosciences, University of Edinburgh,

Drummand Street, Edinburgh EH8 9XP, UK 


\section{Introduction}

General Circulation Models (GCM) project large changes in climate during this century (IPCC 2007a). Most model projections use the IPCC SRES scenarios that illustrate plausible future emission pathways based on different assumptions regarding demographic change and social, economic and technological development (Nakícenovíc et al. 2000). The climate models show that global mean temperature increases in all these scenarios. However, regional climate patterns differ strongly. In general, high latitudes warm most, while tropical regions warm only slightly. Future projections of precipitation are more uncertain (Ruosteenoja et al. 2003).

Climate change is a global phenomenon, but people will be affected by its local impacts. Among other impacts, changing temperature and precipitation patterns will have a profound impact on the natural resource base world-wide, and on the income of people that depend on these resources (IPCC 2007b). Economic analysis of these local impacts of climate change requires modeling of how local natural resources will be affected (in terms of productivity, dynamics, etc.), and, subsequently, how local income and livelihoods will be influenced as a function of changes in resource availability, changes in demand for resources, price developments and adaptation options (e.g. Fischer et al. 1994; Leemans and Eickhout 2004; Schellnhuber et al. 2006). Hence, both ecological and market dynamics have to be accounted for.

Several studies have analyzed the impacts of climate change with comprehensive socio-economic and climate-change scenarios and detailed models, in particular for temperate systems (e.g. Schröter et al. 2005). For tropical systems, there is often insufficient data to model changes in ecosystem productivity as a function of changes in climate, and few studies are available to date, in particular for livestock based production systems. In the words of the IPCC (2007b, p. 459): "very little research has been conducted on the impact of climate change on livestock (in Africa)".

The African Sahel is one of the regions that has been identified as particularly vulnerable for future climate change (Zeng 2003; IPCC 2007b). In the semi-arid Sahel, transhumant livestock herding provides the main source of income for local people. A critical factor in livestock keeping is the annual herbaceous biomass production, which is determined by annual rainfall as well as the applied grazing strategies (Le Houérou 1989; Walker 1993; Briske et al. 2003; Vetter 2005). Hence, livelihoods in the Sahel are strongly dependent on rainfall conditions. Analyzing the local impacts of climate change in the Sahel requires consideration of both changes in rainfall patterns and the potential responses of local pastoralists (Reynolds et al. 2007).

The aim of this paper is to model the potential, local economic impacts of climate change in the Ferlo semi-arid rangeland in Senegal. Specifically, we assess the economic impacts of changes in annual rainfall and its variability, using an ecological-economic model. In view of limited data on local ecosystem productivity and long-term developments in demand for and supply of livestock, a simplified model is used, which nevertheless captures the main dynamics and outputs of the system. The model accounts for rangeland dynamics (cf. Breman and de Ridder 1991; Hein and De Ridder 2006) and price dynamics in local livestock markets (Turner and Williams 2002), and is calibrated for the Ferlo on the basis of local data. The model is used to analyze the economic consequences of seven scenarios involving different changes in average annual rainfall as well as changes in interannual rainfall variability. 
The local impact of climate change is expressed through changes in ordinary profit functions that indicate the profits from livestock grazing under different stocking densities. The profit functions are prepared for the pastoralist community as a whole (i.e., a 'Social Planner' perspective), depicting the overall profits from livestock herding that accrue to the community. The profit functions indicate both the economic efficient grazing strategy under different climate-change scenarios, and the grazing management regimes that can be expected under open access conditions. Clearly, the ordinary profit function is a basic concept that does not do justice to often complex institutional and ownership arrangements. The grazing strategies of Sahelian pastoralists are driven by a whole set of institutions, which govern migration routes, access to pastures and drinking water ponds, etc. (e.g. Le Houérou 1989). In addition, the pastoral society consists of a range of different actors that cannot be expected to behave as one, coordinated, profit maximizing entity, and pastoralists determine their grazing strategies based on a range of criteria, including individual risk aversion and social and institutional factors. Hence, the income and profits that will actually accrue to the pastoralists is a function of the livestock production system as determined by a range of social, institutional and other factors. Nevertheless, the profit function is useful for the purpose of this study, as it indicates the overall, maximal profits that the pastoralist society can obtain as a function of climate change and grazing strategy, as well as the income and stocking density that would be reached in case of a strict open access type of resource management. The limitations as well as the added value of the approach are elaborated in the Section 4.

\section{Methods and data}

\subsection{Area description}

The study area is the Ferlo Region, Northern Senegal (Fig. 1). The natural vegetation consists of dry grassland with scattered trees and bushes. The herbaceous layer comprises a mix of grasses, leguminous species and other plants. While both annual and perennial species occur in the Ferlo, annual species strongly dominate the herbaceous layer (Breman and de Ridder 1991; Hein 2006). Soils are mainly of aeolian origin and are predominantly sandy, with variable but generally small amounts of loam and clay. Annual rainfall varies between around 120 and $450 \mathrm{~mm}$, with an average of $291 \mathrm{~mm}$. The rainy season lasts only 3 months, from July to September (Andre 1998).

With an average population density of around five people per square kilometer, the total rural population of the Ferlo can be estimated at around 110,000 people (Direction de la prévision et de la statistique 1997). Livestock keeping is the main economic activity in the Ferlo and it is essential for local food security. The principal animals kept are cattle (zebu), sheep and goats.

While there is considerable variation among the local pastoralists as a consequence of family size and composition, herd size, etc., transhumance remains the most common production system among the Fulani (Adriansen and Nielsen 2002). Families spend the wet season in the Ferlo, with the herds feeding on the green pastures and water being provided by ponds or boreholes. In recent decades, a substantial number of new wells have been constructed in the Ferlo, drawing water 


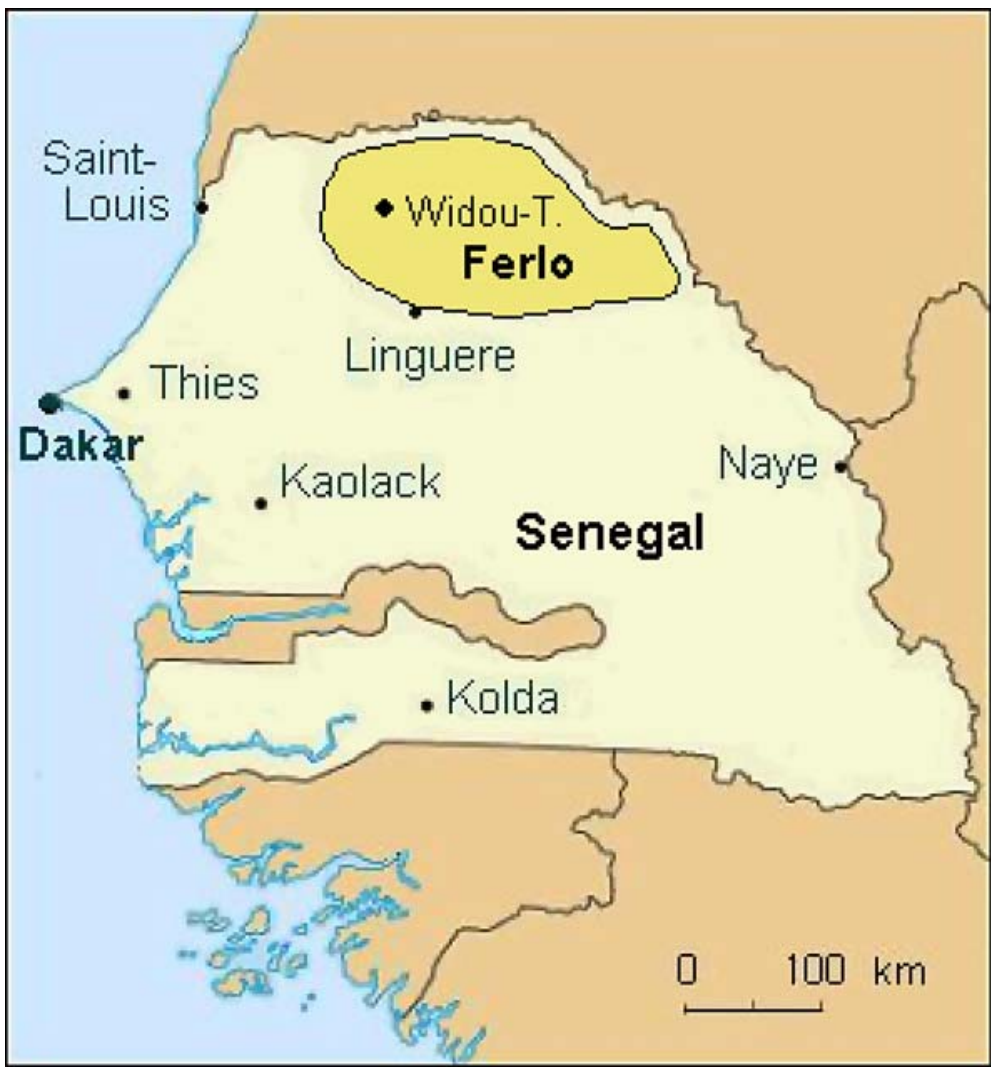

Fig. 1 The Ferlo

from deep aquifers, and perennial water sources are now available throughout the Ferlo (Ministère de l'Hydraulique 1987). The drilling of the boreholes, in combination with government policies aimed at settling local people in order to facilitate their incorporation in the administrative system, caused a concentration of grazing pressures and led to the creation of denuded zones around the wells (Sinclair and Fryxell 1985).

During the dry season ponds dry out, but water is still provided by the boreholes, unless there is a pump failure. Feed resources strongly decline during the dry season, and many of the pastoralists migrate southwards to the more humid Sudan zone, where fallow lands and crop residues provide food for the animals and where more perennial water resources are available (Sutter 1987; Breman and de Ridder 1991; Adriansen and Nielsen 2002). However, since the early 1990s, there has been an expansion of agricultural activities in the Sudan zone, which increasingly limits the possibility for pastoralists to migrate south in the dry season (Guerin et al. 1993; Adriansen 2006).

In recent years there has been an increase in the number of small ruminants, which are more drought resistant. In addition, there has been a trend to increased connection with the livestock markets, with the Fulani becoming more actively 
engaged in selling and buying livestock on local and regional markets (Adriansen 2006). Currently, average livestock densities in the Ferlo are in the order of 0.150.20 Tropical Livestock Units (TLU) per hectare (De Leeuw and Tothill 1990; Miehe 1997). A TLU is an indicator that has been developed to measure livestock production and that corresponds to $250 \mathrm{~kg}$ of animal weight (Boudet 1975). In the Ferlo, a Zebu cow equals on average 0.73 TLU and a sheep or a goat is around 0.12 TLU (Boudet 1975).

\subsection{The ecological-economic model}

An ecological-economic model has been constructed on the basis of local data on vegetation production under different grazing densities and rainfall conditions. These data were collected during a 10-year period (1981-1990) in the WidouThiengoly research station in the western part of the Ferlo (see Fig. 1), as reported in Klug (1982), Miehe (1992, 1997), Andre (1998) and Hein (2006).

The model is a dynamic systems model, running with time increments of 1 year. The model calculates the annual income for the pastoralists as a function of annual rainfall and the long-term stocking rate maintained by the pastoralists. The model is spatially homogeneous, and changes in livestock routes or other adaptation strategies not involving changes in stocking densities are not considered. The structure of the model is shown in Fig. 2. The different steps are explained in detail below. All prices are expressed in CFA, the West-African Franc. ${ }^{1}$

Input variables The model is based on the assumption that it is not water, but grass biomass that is the critical limiting factor for livestock grazing in the Ferlo. The reason is that, in the last decades, a large number of boreholes have been constructed in the area and drinking water for livestock is now generally available also in the dry season. However, in the dry season, grass resources are becoming increasingly scarce and, during drought years, animals are suffering from a lack of feed (Ministère de l'Hydraulique 1987; Adriansen 2006). During a drought, feed resources are also difficult to access by migrating the herds south, because of the agricultural expansion that has taken place here and because, in times of drought, fewer crop residues are available for animal feed (Guerin et al. 1993; Adriansen 2006).

The model contains two input variables: effective annual rainfall and long-term stocking density. Measurements by Miehe (1997) have shown that the average annual rainfall of $291 \mathrm{~mm} \mathrm{year}^{-1}$ results in an effective annual rainfall of $190 \mathrm{~mm}$ year $^{-1}$. The effective annual rainfall is the rain not lost through evaporation or run-off, providing a better indicator of the water availability for plant growth. The model uses a 50 years simulation of annual rainfall, including its variability, based on the actual annual rainfall variability during the period 1961-1990 (as reported in Andre 1998).

Long-term stocking density is a key management variable for semi-arid rangelands (Batabyal et al. 2001; Briske et al. 2003). While pastoralists decide on a year-toyear basis how they move their herds in a spatially heterogeneous rangeland, the long-term stocking density is the key driver for the development of the structure and composition of the plant cover over time (Le Houérou et al. 1988; Walker 1993;

${ }^{1}$ On 1st of June 2006, 1 US $\$=530$ CFA. 
Fig. 2 Structure of the ecological-economic model

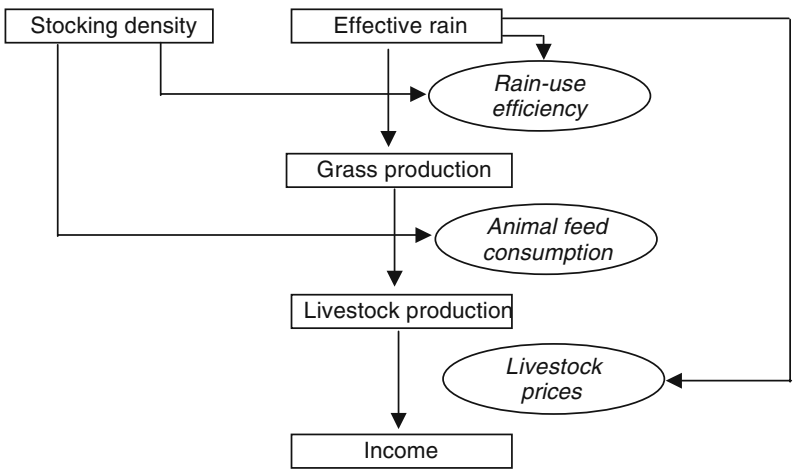

Vetter 2005). The herds in the model comprise a mix of cattle, goats and sheep, and the size of the herd is expressed in Tropical Livestock Units (TLU, see above).

Rain-use efficiency Rain-use efficiency indicates the effectiveness of vegetation to transfer rain into biomass (Le Houérou 1984). Rain-use efficiency is normally expressed as the amount of biomass produced per hectare per year per millimeter of (effective) rain. Analysis of 10 years of grazing data in the Ferlo (Hein 2006) demonstrated that RUE is a quadratic function of rainfall (cf. O'Connor et al. 2001). RUE appears to be relatively high at intermediate levels of rainfall, and RUE declines in years of drought and in years with high rainfall (Hein and De Ridder 2006). In addition to rainfall, the RUE is also affected by the long-term grazing pressure. This reflects that a few years of high grazing pressure have limited impacts on the vegetation, but that sustained high grazing pressure leads to changes in the ecosystem (species composition, cover, etc.; Le Houérou et al. 1988). Impacts of ecosystem changes on the productivity are expressed through changes in the RUE. Specifically, high long-term grazing pressure shifts the quadratic curve downwards, reducing the RUE and, consequently, herbaceous biomass production, for each amount of rainfall (see for details: Hein 2006; Hein and De Ridder 2006). In the model, we use the following formula:

$$
\rho=\left[\alpha r^{2}-2 \alpha R \cdot r+\beta\right]-\left[\left(s^{\circ}\right)^{\vartheta}\left(\mu r^{2}-2 \mu \bar{r} \cdot r+v\right)\right]
$$

$\rho$ denotes the rain-use efficiency $\left(\mathrm{kg} \mathrm{ha}^{-1} \mathrm{~mm}^{-1}\right), r$ the effective annual rainfall $\left(\mathrm{mm}\right.$ year $\left.{ }^{-1}\right), R$ the average rainfall, and $s^{\mathrm{o}}$ the long-term stocking density (TLU $\left.\mathrm{ha}^{-1}\right) . \alpha, \beta, \mu$ and $v$ are scaling parameters, which are estimated on the basis of the grazing data. The left-hand part of the equation is a simple quadratic function showing the relation between rain-use efficiency and rainfall without grazing (cf. O'Connor et al. 2001; Hein and De Ridder 2006). The right hand part of the equation shows how the long-term grazing pressure affects the rain-use efficiency by moving the curve towards a lower rain-use efficiency, while maintaining a quadratic relation (cf. O'Connor et al. 2001). Further explanation of the function is provided in Hein and De Ridder (2006) and Hein and Weikard (2004).

Grass production Grass production is the product of annual effective rainfall and rain-use efficiency. Note that this implies that $F$ is a third power function of the rainfall (cf. Le Houérou et al. 1988; Palmer 2000). It can be specified as follows, 
with $F$ denoting the grass production (above-ground NPP, expressed as kilogram per hectare per year):

$$
F=\rho \cdot r
$$

Livestock production A pasture's annual grass production $F$ can be translated into the annual grazing capacity $s_{\max }$. (Hildreth and Riewe 1963). Let $\varphi$ be the amount of plant biomass required to allow the subsistence of a livestock unit. Then

$$
s_{\max }=\frac{1}{\varphi} F
$$

The actual stocking density in a year, $s_{t}$, depends on $s_{\max }$ in relation to the selected long-term stocking density, $s$. In years with sufficient rainfall, the pastoralists maintain $s^{\mathrm{o}}$. In these years, the reproduction of the stock leads to surpluses $\left(s_{t}-s^{\mathrm{o}}\right)$, which are sold on the market. However, in years where animal feed resources are insufficient due to low rainfall, the pastoralists maintain only as many animals as can be supported by the grass production in that year: $s_{\max }$. The animals that cannot be fed are sold on the market. This is in line with the actual strategies that can be observed in the Ferlo. In years of drought, pastoralists maintain as much animals as possible on the limited grass resources available in order to be able to restock as quickly as possible after the drought, and in years of abundant rainfall, the surplus is sold on the local markets (Guerin et al. 1993). Hence:

$$
s_{t}=\operatorname{Minimum}\left(\mathrm{s}^{\mathrm{o}}, s_{\max }\right)
$$

The growth of the livestock herd is assumed to follow a logistic growth process:

$$
\Delta s=\lambda\left(1-\frac{s_{t}}{s_{\max }}\right) \cdot s_{t}
$$

where $s_{t}$ is livestock in the current year, $\Delta s$ is the gain in livestock, $s_{\max }$ is the grazing capacity of the rangeland determined by the annual rainfall and $\lambda$ is a scaling parameter capturing the potential natural growth in livestock. $\lambda$ is always greater than zero. Note that during droughts, when $s_{t}$ equals $s_{\max }$ (see Eq. 4), there is no gain in livestock. This reflects that during drought the net reproduction rate of the animals is 0 .

Pastoralists income For Senegalese pastoralists, the main source of income is the sale of animals for meat, with milk production coming in second place (Sutter 1987; Guerin et al. 1993). The role of milk production and agriculture has decreased in the last decades with the increased focus on livestock herding for meat production (Adriansen 2006). Off-farm income is relatively unimportant in the Ferlo. The most important off-farm activities are the selling of crafts ( $2 \%$ of income) and the collection and sale of arabic gum (3\% of income; Sutter 1987). Therefore, for reasons of simplicity, in the model it is assumed that income is only derived from the sale of animals. Income depends upon the amount of surplus livestock that can be sold annually on the market, as well as on the livestock price. The amount of livestock that can be sold or bought equals the stock in the previous year $\left(s_{t-1}\right)$ plus the growth 
in livestock $(\Delta s)$ minus the stocking density that is maintained $\left(s_{t}\right)$. The amount of animals the pastoralists sell (positive) or buy (negative; $S$ ) equals

$$
S=s_{t-1}-s_{t}+\Delta s
$$

In years of drought, when there is not enough grass production to feed the livestock number corresponding to the long-term stocking rate, it is assumed that the pastoralists maintain the amount of livestock that can be fed, and that they sell the surplus on the market. However, the price will be low, as there will be a high supply, and low demand on the local markets. If a dry year is followed by a wet year, the pastoralists will purchase livestock in the market in order to stock up to the longterm stocking rate. However, in years subsequent to a drought, prices will generally be high. The profit-function of the pastoralist society is:

$$
\pi=S \cdot p-c \cdot s
$$

With $\pi$ being the profit of the pastoralists per hectare and $p$ the price per livestock unit. The factor $c \cdot s$ indicates the variable costs per livestock unit (e.g. interest and veterinary services). It is assumed that, in the Ferlo, there are no fixed costs (such as land taxes or fencing, which are virtually absent in the Ferlo).

\subsection{Data}

The parameters in Eq. 1 were derived through regression analysis on the basis of the grazing data from the Widou-Thiengoly research station covering the period 19811990 (see Hein 2006). The empirical parameter settings are presented in Table 1. The main outcome of the grazing data was that high grazing pressures have relatively little effect during years with normal or high rainfall, but lead to a strong reduction in grass production during droughts (Hein 2006).

For Eq. 3, the amount of plant biomass required to feed one TLU during 1 year $(\varphi)$ has been estimated on basis of the local livestock mix (see Thébaud et al. 1995) and the energy requirements per animal (Bayer and Waters-Bayer 1998). The minimum amount of feed that the animals need to maintain themselves is estimated at $4.3 \mathrm{~kg}$ $\mathrm{TLU}^{-1} \mathrm{day}^{-1}$. Not all herb biomass is available to the animals, due to decomposition, fire, or the unpalatability of certain plants. Penning de Vries and Djitèye (1982) and Breman and de Ridder (1991) show that, in the Ferlo, 50\% of plant biomass is available for grazing. The dietary contribution of woody plants to the overall feed supply is estimated at $20 \%$ (Breman and de Ridder 1991). Hence, it is estimated that $\varphi$ equals $4.3 \times 365 \times 2 \times 0.8=2511 \mathrm{~kg}$ herb biomass $\mathrm{TLU}^{-1}$ year $^{-1}$.

The livestock population grows according to a logistic growth curve (Eq. 5). Specification of this curve requires estimation of the growth factor of livestock,

Table 1 Parameters for the relation between rainfall, grazing and rain-use efficiency, used to calibrate Eq. 1 ( $n=30$, $F=28$; from Hein and Weikard 2004; Hein 2006)

\begin{tabular}{lc}
\hline Parameter & Value \\
\hline$\alpha$ & -0.00021 \\
$\beta$ & -1.254 \\
$\mu$ & 0.00504 \\
$\nu$ & 210.8 \\
$\theta$ & 2.0 \\
$R$ (average effective rainfall), $\mathrm{mm}$ & 189 \\
\hline
\end{tabular}


$\lambda$. Boudet (1975) and Mortimore and Adams (2001) estimate a maximum natural growth of herd size of around $20 \%$ per year for the western Sahel. It is assumed that this also holds for the Ferlo. This growth rate corresponds to a logistic growth factor $\lambda$ of 0.6 .

The final parameters to be estimated in the model relate to the price of livestock, $p$, and the variable costs related to livestock, $c$. Based upon the average price per animal in the Ferlo and the local livestock mix (Thébaud et al. 1995), the average livestock price is assumed to be $24,750 \mathrm{CFA} \mathrm{TLU}^{-1}$. In the Ferlo, livestock prices decrease during a drought, as many farmers want to sell livestock that they cannot feed. Immediately after a drought, livestock prices increase substantially as farmers want to restock (Turner and Williams 2002). For the Ferlo, data on price fluctuations are not available. Therefore, as the best proxy available, data on price fluctuations from western Niger have been used. This area has a slightly higher average rainfall but otherwise represents a comparable physical, economic and social environment. The production system is also based on transhumant livestock ranging, and the local population is also dominated by Fulani. Based on these data, it is assumed in the model that prices drop to $43 \%$ during years with a drought and that they increase to $146 \%$ in the 2 years subsequent to a drought.

Regarding the costs of livestock herding in northern Senegal, it is assumed that all costs are variable costs, related to capital and labor inputs required to maintain the herd. The capital costs per livestock unit amount to the local, real interest rate times the price of a livestock unit. Currently, the average local interest rates are around $18 \%$ (Ndour and Wané 1998), and the annual inflation in Senegal is approximately $2 \%$ (IMF 1999). The capital costs are, therefore, $0.16 \times 24750=3960 \mathrm{CFA} \mathrm{TLU}^{-1}$. The average labor costs in rural Senegal are estimated at 100,000 CFA per person per year (Direction de la prévision et de la statistique 1997). These costs only incur during the period January-June when the herds are moved south (Guerin et al. 1993), as during the rainy season herds are taken care of by various family members, including children, at no costs. With an average herd size of 44 TLU per family (Thébaud et al. 1995), the annual labor costs amount to $100,000 / 44 / 2=1,140 \mathrm{CFA} \mathrm{TLU}^{-1}$. Therefore, the total variable costs are $3,960+1,140=5,100 \mathrm{CFA} \mathrm{TLU}^{-1}$.

\subsection{The scenarios}

The IPCC has developed a range of alternative emissions scenarios, based on different socio-economic development pathways for the twenty-first century (Nakícenovíc et al. 2000). There is broad agreement between the general circulation models (GCMs), which were run for the IPCC emissions scenarios, that mean global surface temperature is likely to rise between $2.0^{\circ} \mathrm{C}$ and $4.5^{\circ} \mathrm{C}$ by the end of the century (IPCC 2007a). However, these models have great difficulty in projecting future climate for the Sahel region (Hulme et al. 2001; Held et al. 2005). For the present study we therefore examined the changes in climate in the 2050s as projected by six GCMs for the six IPCC SRES scenario groups (Nakícenovíc et al. 2000; IPCC 2007a). These scenarios project future greenhouse gas emissions, atmospheric concentrations and climate, assuming no climate-change abatement. The A1 scenario group describes a future world of rapid economic growth, global population that peaks in midcentury, a fast introduction of new technologies and convergence among regions. Scenario A1F is fossil fuel intensive, A1B has a balanced energy mix and A1T has 
a focus on renewables. The A2 scenario describes a world in which regions develop more autonomously. Economic development is primarily regionally oriented and a continuously growing population is assumed. The $\mathrm{B} 1$ storyline describes a convergent world with a peaking and subsequently declining world population, with a focus on a service and information oriented world economy. The B2 scenario family emphasizes local solutions to economic, social and environmental sustainability, assuming a continuously increasing global population (Nakícenovíc et al. 2000).

Although our model only considers climatic changes, which are available at the required level of detail for our analysis, the contrasting future worlds that characterize the SRES scenarios can also be used to interpret the model outcomes, as discussed in Section 4.2. Temperature is not a limiting factor for vegetation growth in the Sahel region and most GCMs only show small increases here. Such an increase could enhance evapotranspiration and thus reduce rain use efficiency. We assumed that this effect is small and negligible in comparison with the projected changes in precipitation. We therefore only used changes in precipitation as the major scenario driver in this study.

Precipitation change from 2035 to 2064 compared to $1969-1990$ was extracted for the GCM grids cells that best covered the Ferlo study area $\left(15^{\circ} \mathrm{N} 20^{\circ} \mathrm{N}, 16^{\circ} \mathrm{W}\right.$ $21^{\circ} \mathrm{W}$ ). These climate data are available through the IPCC data distribution centre (http://ipcc-ddc.cru.uea.ac.uk), which also provides elaborate descriptions of the GCMs and the SRES scenarios. Unfortunately, not all scenarios have been computed by each GCM: only A2 (high emissions) and B2 (low emissions) are available for all GCMs. In addition, the HadCM3 was run for an ensemble of simulations with slightly different initial conditions. There are substantial differences between the projections, both between and within scenarios, see Table 2. Most GCMs project a considerable decrease in rainfall for all scenarios. NIES99 is the only exception, with a slight increase in precipitation for the scenario with low emissions (i.e. B1).

In order to facilitate interpretation and to limit the number of model runs of our ecological-economic model, we decided to use four precipitation scenarios representing different levels of change in annual rainfall: $-30 \%,-15 \%, 0 \%$ and

Table 2 Projections of relative change in annual rainfall in 2040-2069, compared to 1961-1990, for 6 General Circulation Models and all IPCC SRES scenarios

\begin{tabular}{|c|c|c|c|c|c|c|c|}
\hline \multirow{2}{*}{$\begin{array}{l}\text { Model name } \\
\text { and version }\end{array}$} & \multirow{2}{*}{ Origin } & \multicolumn{6}{|c|}{ IPCC SRES Scenario } \\
\hline & & $\overline{\mathrm{A} 1 \mathrm{~F}}$ & A1B & A1T & $\mathrm{A} 2$ & B1 & B2 \\
\hline HadCM3 & Hadley Centre, UK & -0.52 & & & $\begin{array}{l}-0.52 \\
-0.30 \\
-0.26\end{array}$ & -0.43 & $\begin{array}{l}-0.43 \\
-0.26\end{array}$ \\
\hline CGCM2 & Canadian Centre for Climate Change & & & & -0.09 & & -0.18 \\
\hline CSIRO-Mk2 & CSIRO, Australia & & -0.35 & & -0.18 & -0.18 & -0.09 \\
\hline ECHAM4 & Max Planck Institute, Hamburg, Germany & & & & -0.30 & & -0.22 \\
\hline GFDL-R30 & Geophysical Fluid Dynamics Centre, USA & & & & -0.22 & & -0.22 \\
\hline CCSR/NIES & $\begin{array}{l}\text { Centre for Climate System Research } \\
\text { (University of Tokyo) and the National } \\
\text { Institute for Environmental Studies, Japan }\end{array}$ & 0.09 & -0.06 & -0.01 & 0.08 & 0.17 & 0.08 \\
\hline
\end{tabular}

Some GCMs have simulated a scenario multiple times, which is represented by listing multiple results. Data were extracted from the IPCC data distribution centre, which also provides descriptions of the GCMs (http://ipcc-ddc.cru.uea.ac.uk/) 
Table 3 Eight scenarios for climate change in the Ferlo region of the western Sahel

\begin{tabular}{lll}
\hline Scenario & $\begin{array}{l}\text { Change in annual } \\
\text { rainfall }\end{array}$ & $\begin{array}{l}\text { Change in rainfall } \\
\text { variability }\end{array}$ \\
\hline Baseline & 0 & 0 \\
A & $-15 \%$ & 0 \\
B & $-30 \%$ & 0 \\
C & $+15 \%$ & 0 \\
D & 0 & $+20 \%$ \\
E & $-15 \%$ & $+20 \%$ \\
F & $-30 \%$ & $+20 \%$ \\
G & $+15 \%$ & $+20 \%$ \\
\hline
\end{tabular}

$+15 \%$. These values represent the range of the GCMs and provide a likely magnitude of potential rainfall change in the Sahel. For these scenarios, the rainfall pattern (the sequence of dry and wet years) of the period 1961-1990 has been maintained, but the amount of annual rainfall has been adjusted according to the specifications of the scenario. Scenario A $(-15 \%)$ matches with the findings of Held et al. (2005), who project a $14 \%$ drying for the whole Sahel region in the 2050s. Held et al. (2005) argue that the CM2 GCM successfully reproduced the observed drying trends of the 1970 s and 1980s, and that continued drying is likely.

With respect to changes in interannual rainfall variability, there is little information available from these GCM simulations. Giorgi (2006) indicates that an increase in rainfall variation is likely, but there are no projections of how much variability could change. Therefore, for this paper, two possibilities have been analyzed: no change in rainfall variation and a $20 \%$ increase in rainfall variation. The latter has been simulated by stretching the rainfall probability density function by $20 \%$ (i.e. an annual rainfall of one SD minus the average becomes 1.2 SD minus the average). This, for example, increases the amount of dry years ( $<200 \mathrm{~mm}$ rain) between 1961 and 1990 from 6 to 10 years. Table 3 presents the resulting eight scenarios with different changes in rainfall, with or without changes in variability. Scenario B and $F$ align with the SRES scenario groups that assume fossil fuel intensive economic development, in particular A1F, A1B and A2. Scenarios A and E align with SRES scenario groups involving lower greenhouse gas emissions, in particular B1 and B2. However, because of the uncertainty in forecasting precipitation changes in the Sahel, even within SRES scenario groups, there is no complete match between the Scenarios that we selected and the SRES scenarios. Rather, the Scenarios in Table 3 are meant to provide insight in the potential implications of climate change in the Sahel over a range of potential impacts.

\section{Results}

The results of the model calculations are presented in the form of profit functions. The profit functions indicate the surplus that pastoralists gain, valuing inputs including labor and outputs at the appropriate market rates. In the model, all inputs are assumed to have constant prices, but variable livestock prices have been accounted for. The implications of these assumptions are elaborated in the Section 4. The functions present the average annual profits over the 30 years period of the simulation, see Fig. 3. The management variable of the pastoralist community is 
the overall long-term stocking rate, which is assumed to be constant throughout the 30 years period. The profit functions indicate both the long-term stocking rate where the pastoralist community as a whole can obtain maximum profits and the open access equilibrium stocking rate, where profits (but not income) approach zero.

Under current rainfall conditions (Baseline Simulation), Fig. 3 shows maximum profits of $410 \mathrm{CFA} \mathrm{ha}^{-1}$ year $^{-1}$ at a stocking density of around $0.1 \mathrm{TLU}^{-1}$. Note that $0.1 \mathrm{TLU} / \mathrm{ha}$ is consistent with the optimal stocking density suggested by Boudet (1975) for the Ferlo. It also shows the stocking density where no profit is made, around $0.17 \mathrm{TLU} \mathrm{ha}^{-1}$. This corresponds well with the current stocking in the Ferlo, which is estimated at 0.15 to $0.20 \mathrm{TLU} \mathrm{ha}^{-1}$ (De Leeuw and Tothill 1990; Miehe 1997). Hence, the calculations indicate that the Ferlo is currently managed as an open access, common property resource. This is in line with Le Houérou (1989) and Guerin et al. (1993), who state that while the migration routes of pastoralists are determined by a complex set of institutions, there is little institutional control of the amount of animals that each pastoralist keeps. Note that, although current profits from livestock keeping appear to be close to zero, the income that pastoralists
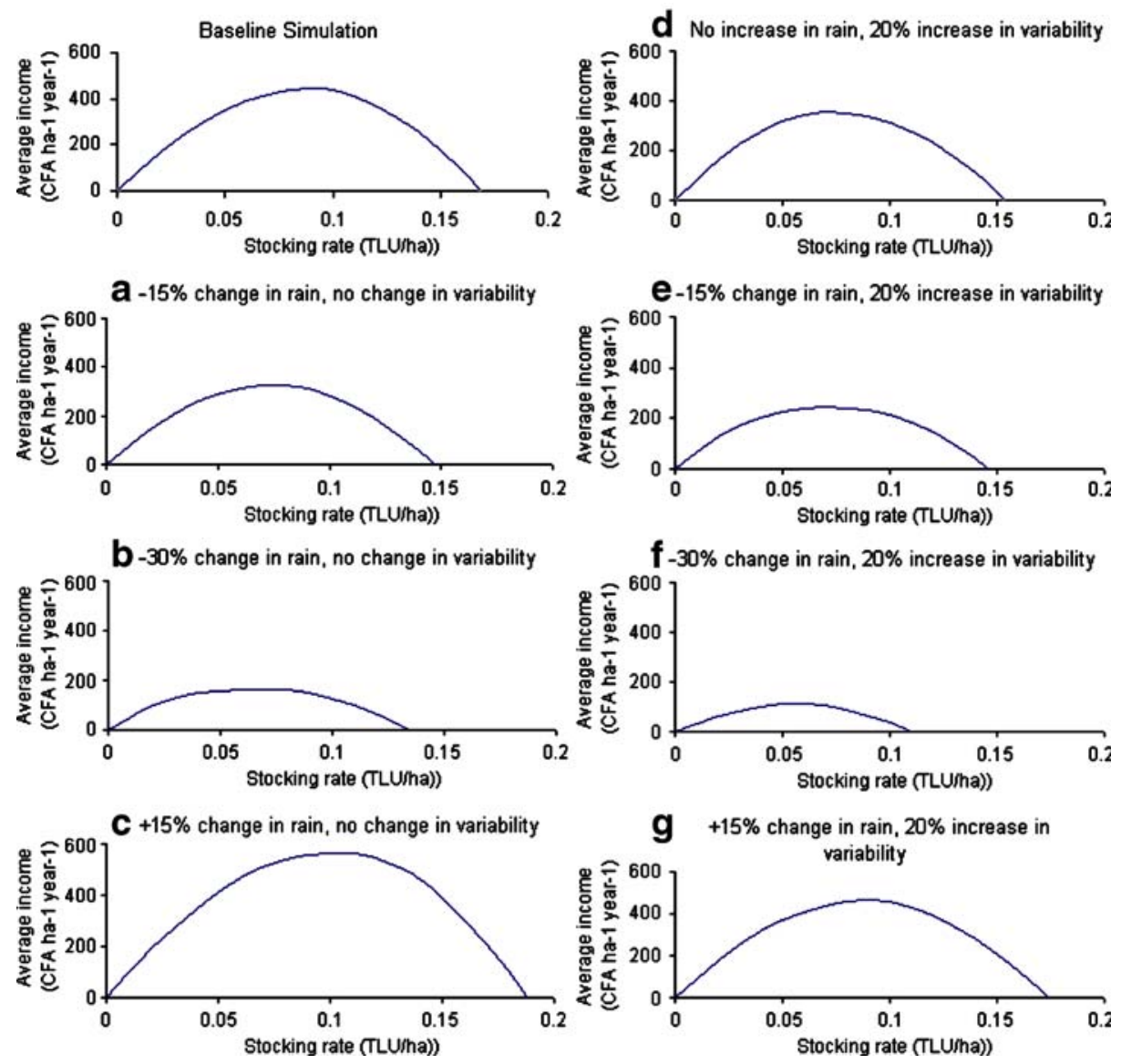

Fig. 3 Profit functions for rangeland management in eight scenarios 
gain at the current stocking density (the reward for their labor) is around 1,140 per TLU $\times 0.17 \mathrm{TLU} \mathrm{ha}^{-1}=194 \mathrm{CFA} \mathrm{ha}^{-1}$.

The model has also been run for the 30 years period of 2035-2064 for the seven different scenarios (as specified in Table 3). The initial conditions of the model $s_{t=0}$, are assumed to equal the long-term stocking density, $s^{\mathrm{o}}$. The 'no-change in variability' scenarios (A to C) clearly show that changes in rainfall amounts will affect the profit function. This has implications for both the optimal stocking density and for the actual stocking density that can be expected under open-access conditions. In case rainfall decreases with $15 \%$, the optimal stocking density is reduced from 0.1 to $0.08 \mathrm{TLU} \mathrm{ha}^{-1}$. If rainfall decreases with $30 \%$, the optimal stocking density is further reduced, to $0.06 \mathrm{TLU} \mathrm{ha}^{-1}$. The corresponding maximum profits the pastoralists can obtain is reduced to 330 and $165 \mathrm{CFA} \mathrm{ha}^{-1}$ year $^{-1}$, respectively. Hence, compared to the present rainfall conditions, pastoralists could adapt to climate change by destocking, which would increase the societal profits gained per livestock unit as well as the overall profits compared to the current grazing strategy. However, if the pastoralists maintain an open-access individual profit maximization strategy, this amount of destocking would not occur. In this case, a more limited destocking can be expected, because the open access equilibrium stocking rate is reduced from the current 0.17 to $0.15 \mathrm{TLU}^{-1}$ in Scenario A and to 0.13 TLU $\mathrm{ha}^{-1}$ under Scenario B. Note that these lower livestock densities will also reduce the demand for labor in the Ferlo. An increase in rainfall (Scenario C) would allow a significant change in profits at current stocking densities, from close to zero to around $180 \mathrm{CFA} \mathrm{ha}{ }^{-1}$ year $^{-1}$. However, it is likely that, in the longer term, pastoralists would adjust to an increase in rainfall by expanding the size of their herds, to around 0.18-0.19 $\mathrm{TLU} \mathrm{ha}^{-1}$.

In Scenarios D to G, there is a $20 \%$ increase in rainfall variability. Even when the amount of rainfall does not change, this is shifting the profit function towards the origin, resulting in a lower maximum profit and a reduced open access equilibrium stocking density. This vulnerability for changes in rainfall variation stems from the strong impact of drought on herbaceous biomass production, in particular if the resilience of the system has been reduced by continuous high grazing pressures (see also Hein 2006). For instance, a change in variability combined with a $15 \%$ reduction in rainfall (Scenario E) further reduces the maximum profits, to $244 \mathrm{CFA}$ per year at a stocking density of $0.07 \mathrm{TLU} \mathrm{ha}^{-1}$. Since the herds take a number of years to recover subsequent to a drought, the system is relatively vulnerable to a combination of reduced rainfall and increased variability in rainfall.

\section{Discussion}

\subsection{The robustness of the model}

The model is built around a limited number of relationships that capture the main characteristics of rangeland dynamics and pastoralists' income. Key sources of uncertainty in the model relate to (1) the rainfall projections; (2) the grazing strategy of pastoralists; (3) the impact of grazing and rainfall on herbaceous biomass production; and (4) market and price developments.

As indicated before, GCMs have great difficulty in modeling the Sahel, in part due to complex relations between sea surface temperatures and Sahelian drought 
(Giannini et al. 2003; Zeng 2003). As a result, future projections for this region are especially uncertain, and a wide range of possible scenarios should be taken into account. Nevertheless, recent literature indicates that a dramatic drying trend should be seriously considered (Held et al. 2005). In this study, the uncertainty related to the rainfall scenarios is addressed by considering the full range of IPCC SRES emission scenarios and a series of different GCMs.

The impact of grazing and rainfall variability has been modeled according to Hein (2006). For the Widou-Thiengoly research station in the Ferlo, Eq. 1 appeared to be significant at $p=0.05$. However, there is considerable spatial (and temporal) heterogeneity in semi-arid rangelands including the Sahel (Turner 1991; McPeak 2003), for instance with respect to rainfall, soils and vegetation composition. The transhumance system allows pastoralists to make best use of the available resource base by moving herds to areas where rainfall has been relatively favorable and where the best pastures occur. In general, this is consistent with the model in that the model also assumes that, at a given time and for a given livestock density, pastoralists make the most efficient use of the available resources. In reality, there may be zones where there is relative over- and relative undergrazing of resources, for example as a function of distance to the boreholes. This spatial variety is not covered in the model and, consequently, the model cannot be used to make any forecasts regarding the impact of climate change at a finer scale than the Ferlo as a whole.

Furthermore, the model does not account for multiple equilibriums of vegetation succession in rangelands. The existence of these equilibriums has been demonstrated in relation to the ratio grass-woody plants cover (Friedel 1991; Laycock 1991) and in relation to the ratio grass cover-bare soil (Van de Koppel et al. 2002; Scheffer et al. 2001). Our model does not include the dynamics of transitions between these equilibriums and, hence, they are applicable only to systems that are dominated by herbaceous plants such as the Ferlo. However, in the Ferlo, high pressures on woody species for fuelwood could prevent a shift to a state dominated by trees and shrubs (Sinclair and Fryxell 1985). Perennial species are, compared to annuals, more sensitive to drought and to intensive livestock grazing (Breman and de Ridder 1991). Hence, with the forecasted reductions in rainfall in the Sahel and the subsequent increase in pressures from livestock grazing, it is unlikely that perennial species will become more abundant. However, increasing drought and grazing pressure may lead to an increase in the denuded zones around the boreholes. The model does not allow analyses at this level of detail.

With respect to grazing strategies, it is assumed that, in surplus years, pastoralists will sell all livestock exceeding the long-term stocking density. This is a simplification, as some pastoralists may decide to temporarily maintain higher stocking rates, e.g. in case they expect to need income at some point in the future. In the absence of banks, livestock functions not only as a means of generating income, but also as a way of storing wealth. However, it is assumed that the current model captures the main response of the pastoralists to changes in rainfall. Grosso modo, farmers will keep as much livestock as possible during droughts when prices are very low, and sell during times of surplus. We have not addressed the risk attitude of pastoralists. In general, pastoralists tend to be risk-averse, and prefer to avoid years with below average income (Anderson and Dillon 1992; Hardaker 2000). Accounting for riskaversion of pastoralists may lead to a reduction of the calculated optimal stocking 
density as such a strategy would reduce the risks of droughts by maintaining the resilience of plant cover to cope with droughts (Hein 2006).

An important simplification of the model is that it is assumed that the prices of inputs, in particular labor, as well as the demand for livestock products will not change in the coming five decades. This, however, is probably not accurate because Senegal is experiencing fast population growth, which is forecasted to continue until at least 2050 in all SRES scenario families. Therefore, the demand for and prices of livestock products could increase. This would lead to higher profits for livestock holders compared to the presented models. The Ferlo region has very few alternative employment opportunities besides livestock herding. Increased population pressure and reductions in labor requirements from reduced stocking densities could decrease wages and labor costs. Including reduced labor costs would increase profits, and lead to higher optimum and open access stocking densities, as the costs of livestock herding would decrease. At the same time, wages for local pastoralists would go down. These effects can only be properly modeled with a general equilibrium model (which would be much harder to link to ecosystem dynamics), and these effects are therefore not considered in the current model. Hence, the current model only presents a first step towards better understanding of the local economic impacts of climate change in the Sahel. Further coupling of ecological impacts with market dynamics is required in subsequent steps.

\subsection{Interpretation of the model outcomes}

The model demonstrates that changes in average annual rainfall or rainfall variability would have a strong impact on the livelihood of the Fulani pastoralists in the Ferlo. Both the overall profits form livestock keeping, and the per hectare income that can be obtained from this sector will be reduced in case of lower rainfall. For example, the model indicates that a $15 \%$ decrease in rainfall (as projected by Held et al. 2005) in combination with a $20 \%$ increase in rainfall variability would lead to a $15 \%$ reduction in the open access stocking density, and a $30 \%$ reduction in the optimum stocking density. In view of the lack of alternative sources of income in the area, in this case a significant part of the population could be expected to move out of the Ferlo.

The model also shows that, through reduction of the overall stocking density, part of the negative impacts of rainfall reductions could be mitigated. Pastoralists should adapt to reductions in rainfall by destocking of livestock in order to obtain higher economic benefits per hectare, compared to the present management strategies. However, such adaptations will be very difficult to achieve, as stocking rates are controlled by $10,000 \mathrm{~s}$ of individual pastoralists and there is little government control of stocking rates. While active steering of stocking rates in the face of climate change may be complex, the government may want to consider more passive ways of reducing herd sizes in case of persistent rainfall reductions, for instance by not supporting the drilling of additional wells or enhancing veterinary support in the area.

The model did not account for potential changes in the political, institutional or social structures governing livestock ranging in the Ferlo. The SRES scenarios offer potential regional trends in these structures at the level of Sub-Saharan Africa, which are difficult to interpolate to the Ferlo. The last decades have seen rapid changes in the Ferlo, for instance an increased sedentarisation, reduction of livestock migration 
and herding in the rainy seasons as animal are kept close to the boreholes, and a general trend of outward migration (Bradley and Grainger 2004; Adriansen 2006). In response to droughts and increased access to markets, the number of small ruminants has increased, with sheep raising for the Tabaski festival providing additional cash income (Adriansen 2006). Depending on the opening up of international markets for livestock products from Senegal (SRES Scenarios A1 and B1), pastoralists may become further engaged in producing for national or international markets. A continuous high population growth in the Ferlo (A2 and B2) would probably further increase the already high pressure on the ecosystem resources. However, with a trend towards decreasing rainfall, which limits the possibilities for other types of agriculture, and a strong cultural preference for livestock herding among the Fulani (Le Houérou 1989; Adriansen and Nielsen 2002), it is difficult to imagine other production systems replacing livestock ranging in the coming decades.

\section{Conclusions}

This paper presents a model for the analysis of the potential, local economic impacts of climate change in the Ferlo in the Western Sahel. The model is based on local long-term time series of rangeland productivity and livestock prices under different rainfall conditions. The model follows a Social Planner approach, calculating impacts of climate change to the pastoralist society as a whole. The model does not capture spatial variation in grass production. As for most of Sub Saharan Africa's drylands, with the possible exception of South Africa (e.g. O'Connor et al. 2001), there is a general lack of data required to model the impacts of climate change on the local dryland production system. These data constraints restrict the level of detail that can be incorporated in the model. While the model is calibrated to the Ferlo, its basic premises would also be applicable to other rangelands, in particular those rangelands dominated by annual grasses.

The model illustrates how changes in annual rainfall in combination with changes in rainfall variability affect the optimal livestock stocking density, as well as the stocking density that can be expected under open access conditions. The model indicates that, in spite of complex institutional arrangements guiding the access of pastoralists to pastures, the Ferlo currently appears to be managed as an open access resource (cf. Le Houérou 1989). While existing institutions govern migration routes and access rights (e.g. Guerin et al. 1993), they may pose few restrictions on the amount of livestock each pastoralist keeps.

The model shows that a modest reduction in rainfall would have a considerable impact on the profits that can be derived from livestock keeping. For instance, in case rainfall decreases with $15 \%$, the optimal stocking density is reduced from 0.1 to $0.08 \mathrm{TLU} \mathrm{ha}^{-1}$, and the maximum profits the pastoralists can obtain are reduced from 410 to $330 \mathrm{CFA} \mathrm{ha}^{-1}$ year $^{-1}$. In addition, it is shown that the system is highly sensitive to increased interannual variability in rainfall, because the impact of dry years on grass production is severe and the livestock herds need several years to recover after drought. Pastoralists can adapt to reductions in rainfall by destocking of livestock in order to obtain higher economic benefits per hectare, compared to the present management strategies. However, such adaptations will be very difficult to achieve, as stocking rates are controlled by individual pastoralists with little government control. 
The model outcomes suggest that, even when livestock densities are maintained close to the open access equilibrium, there would be a reduction in livestock numbers in the Ferlo in the coming decades, forced by decreasing animal feed resources. Although the model does not allow analysis of consequent changes in the local labor markets, a reduction in livestock numbers may lead to reduced employment opportunities in the Ferlo and a further pressure on local people to move out of the area.

Open Access This article is distributed under the terms of the Creative Commons Attribution Noncommercial License which permits any noncommercial use, distribution, and reproduction in any medium, provided the original author(s) and source are credited.

\section{References}

Adriansen HK (2006) Continuity and change in pastoral livelihoods of Senegalese Fulani. Agric Human Values 23:215-229

Adriansen HK, Nielsen TT (2002) Going where the grass is greener: on the study of pastoral mobility in Ferlo, Senegal. Hum Ecol 30(2):215-226

Anderson JR, Dillon JL (1992) Risk analysis in dryland farming systems. Farm systems management series 2. FAO, Rome

Andre D (1998) 17 ans de suivi de la vegetation ligneuse et herbacée dans le périmètre expérimental de Widou-Thiengoly, Ferlo, Nord Sénégal. Projet d'autopromotion pastorale dans le Ferlo (PAPF). Sénégal, Saint-Louis

Batabyal AA, Biswas B, Godfrey EB (2001) On the choice between the stocking rate and time in range management. Environ Resour Econ 20(3):211-223

Bayer W, Waters-Bayer A (1998) Forage husbandry. Technical centre for agricultural and rural cooperation. CTA, Wageningen

Boudet G (1975) Manuel sur les pâturages tropicaux et les cultures fourragères. Editions du Ministère de la Coopération, Paris

Bradley D, Grainger A (2004) Social resilience as a controlling influence on desertification in Senegal. Land Degrad Dev 15(5):451-470

Breman H, de Ridder N (1991) Manuel sur les pâturages des pays sahéliens. ACCT—CTA— Karthala Editions. CTA, Wageningen

Briske DD, Fuhlendorf SD, Smeins FE (2003) Vegetation dynamics on rangelands: a critique of the current paradigms. J Appl Ecol 40:601-614

De Leeuw PN, Tothill JC (1990) The concept of rangeland carrying capacity in Sub-Saharan Africamyth or reality. Pastoral Development Network Paper 29. Overseas Development Institute, London

Direction de la prévision et de la statistique, Ministère de l'Economie, des Finances et du Plan, Sénégal (1997) Enquête Sénégalaise auprès des Ménages. Mars 1994-Avril 1995

Fischer G, Frohberg K, Parry ML, Rosenzweig C (1994) Climate change and world food supply, demand and trade: who benefit, who loses? Glob Environ Change 4:7-23

Friedel MH (1991) Range condition assessment and the concept of thresholds: a viewpoint. J Range Manag 44:422-426

Giannini A, Saravanan R, Chang P (2003) Oceanic forcing of Sahel rainfall on interannual to interdecadal time scales. Science 302:1027-1030

Giorgi F (2006) Climate change hot-spots. Geophys Res Lett 33(8):L08707

Guerin H, Friot D, Mbaye ND, Richard D (1993) Alimentation des ruminants domestiques sur pâturages naturels Sahéliens et Sahelo-Soudaniens. Rapport \# 39, Institut Sénégalais de recherches agricoles. Dakar, Sénégal

Hardaker JB (2000) Some issues in dealing with risk in agriculture. Working paper agricultural and Resource Economics Group. University of New England, Armidale

Hein L (2006) The impact of grazing and rainfall variability on the productivity of semi-arid rangelands. J Arid Environ 64:488-504

Hein L, De Ridder N (2006) Desertification in the Sahel; a reinterpretation. Glob Chang Biol 12:1-8 
Hein L, Weikard HP (2004) Managing stochastic dynamic rangelands: livestock grazing in a Sahelian rangeland. In: Proceedings 13th European association of environmental and resource economists conference, Budapest, 25-28 June 2004

Held IM, Delworth TL, Lu J, Findell KL (2005) Simulation of Sahel drought in the 20th and 21st centuries. Proc Natl Acad Sci U S A 102:17891-17896

Hildreth RJ, Riewe ME (1963) Grazing production curves II: determining the economic optimum stocking rate. Agron J 55:367-369

Hulme M, Doherty R, Ngara T, New M, Lister D (2001) African climate change: 1900-2100. Clim Res 17:145-168

IMF (1999) Press Release No. 99/29, Annex: programme summary Senegal enhanced structural adjustment facility. International Monetary Fund, Washington, DC

IPCC (2007a) Climate change 2007: synthesis report. Contribution of working groups I., II and III to the fourth assessment report of the intergovernmental panel on climate change. IPCC, Geneva, Switzerland

IPCC (2007b) Climate change 2007: impacts, adaptation and vulnerability. Contribution of Working Group II to the fourth assessment report of the intergovernmental panel on climate change (IPCC). Cambridge University Press, Cambridge

Klug S (1982) Inventaire et suivi de la vegetation dans la parcelle d'elevage a Vindou-Tiengoly (Ferlo-Senegal). GTZ, Hamburg

Laycock WA (1991) Stable states and thresholds of range condition on North American rangelands: a viewpoint. J Range Manag 44:427-433

Leemans R, Eickhout B (2004) Another reason for concern: regional and global impacts on ecosystems for different levels of climate change. Glob Environ Change 14:219-228

Le Houérou HN (1984) RUE: a unifying concept in arid land ecology. J Arid Environ 7:213-247

Le Houérou HN (1989) The grazing land ecosystems of the African Sahel. Springer, Berlin

Le Houérou HN, Bingham RL, Skerbek W (1988) Relationship between the variability of primary production and the variability of annual precipitation in world arid lands. J Arid Environ 15:1-18

McPeak JG (2003) Analyzing and addressing localized degradation in the commons. Land Econ 79:515-536

Miehe S (1992) L'evolution de la strate herbacée au cours de la nouvelle sécheresse 1990-1992. Rapport d'une mission à court terme. GTZ, Eschborn

Miehe S (1997) Inventaire et suivi de la végétation dans le Périmètre expérimental à WidouThiengoly dans le cadre du projet Sénégalo-Allemand d'autopromotion pastorale dans le Ferlo (PAPF). Rapport 1997. GTZ, Eschborn

Ministère de l'Hydraulique (1987) Plannification des Resources en Eau - Bilan-diagnostique. Rapport SEN/87/006. Ministère de l'Hydraulique, Dakar, Senegal

Mortimore MJ, Adams WM (2001) Farmer adaptation and 'crisis' in the Sahel. Glob Environ Change 11:49-57

Nakícenovíc N, Alcamo J, Davis G, de Vries B, Fenhann J, Gaffin S, Gregory K, Grübler A, Jung TY, Kram T, Emilio la Rovere E, Michaelis L, Mori S, Morita T, Pepper W, Pitcher H, Price L, Riahi K, Roehrl A, Rogner H-H, Sankovski A, Schlesinger ME, Shukla PR, Smith S, Swart RJ, van Rooyen S, Victor N, Dadi Z (2000) Special report on emissions scenarios. Cambridge University Press, Cambridge, pp 599

Ndour H, Wané A (1998) Financial intermediation and poverty in Senegal, EAGER. Research. Dakar, Senegal

O’Connor TG, Haines LM, Snyman HA (2001) Influence of precipitation and species composition on phytomass of a semi-arid African grassland. J Ecol 89(5):850-860

Palmer AR (2000) Description of the grazing capacity information system (GCIS). Report Range and Forage Institute. Range and Forage Institute, Grahamstown

Penning de Vries FWT, Djitèye MA (1982) La Productivité des Pâturages Sahéliens, une Étude des Sols, des Végétations et de L'exploitation de Cette Ressources Naturelle. Centre for Agricultural Publishing and Documentation, Wageningen

Reynolds JF, Stafford-Smith DM, Lambin EF, Turner BL, Mortimore M, Batterbury SPJ, Downing TE, Dowlatabadi H, Fernandez RJ, Herrick JE, Huber-Sannwald E, Jiang H, Leemans R, Lynam T, Maestre FT, Ayarza M, Walker B (2007) Global desertification: building a science for dryland development. Science 316:847-851

Ruosteenoja K, Carter TR, Jylhä K, Tuomenvirta H (2003) Future climate in world regions: an intercomparison of model-based projections for the new IPCC emission scenarios. The Finnish Environment 644. Finnish Environment Institute, Helsinki 
Scheffer M, Carpenter S, Foley JA, Folke C, Walker B (2001) Catastrophic shifts in ecosystems. Nature 413:591-596

Schellnhuber HJ, Cramer W, Nakícénovic N, Wigley T, Yohe G (2006) Avoiding dangerous climate change. Cambridge University Press, Cambridge, $\mathrm{p} 406$

Schröter D, Cramer W, Leemans R, Prentice IC, Araujo MB, Arnell NW, Bondeau A, Bugmann H, Carter TR, Gracia CA, de la Vega-Leinert AC, Erhard M, Ewert F, Glendining M, House JI, Kankaanpaa S, Klein RJT, Lavorel S, Lindner M, Metzger MJ, Meyer J, Mitchell TD, Reginster I, Rounsevell M, Sabate S, Sitch S, Smith B, Smith J, Smith P, Sykes MT, Thonicke K, Thuiller W, Tuck G, Zaehle S, Zierl B (2005) Ecosystem service supply and vulnerability to global change in Europe. Science 310:1333-1337

Sinclair ARE, Fryxell JM (1985) The Sahel of Africa: ecology of a disaster. Can J Zool 63:987-994

Sutter JW (1987) Cattle and inequality: herd size differences and pastoral production among the Fulani of North Eastern Senegal. Africa 57:196-218

Thébaud B, Grell H, Miehe S (1995) Recognising the effectiveness of traditional grazing practices: lessons from a controlled grazing experiment in northern Senegal. Drylands Programme, International Institute for Environment and Development, London. Paper No. 55

Turner MD (1991) Spatial and temporal scaling of grazing impact on the species composition and productivity of Sahelian annual grasslands. J Arid Environ 41:277-297

Turner MD, Williams TO (2002) Livestock market dynamics and local vulnerabilities in the Sahel. World Dev 30(4):683-705

Van de Koppel J, Rietkerk M, van Langevelde F, Kumar L, Klausmeier CA, Fryxell JM, Hearne JW, van Andel J, de Ridder N, Skidmore A, Stroosnijder L, Prins HHT (2002) Spatial heterogeneity and irreversible vegetation change in semi-arid grazing systems. Am Nat 159:209-218

Vetter S (2005) Rangelands at equilibrium and non-equilibrium: recent developments in the debate. J Arid Environ 62:321-341

Walker BH (1993) Rangeland ecology: understanding and managing change. Ambio 22:80-87

Zeng N (2003) Drought in the Sahel. Science 302:999-1000 